\title{
Dampak Covid - 19 Dalam Stabilitas Ekonomi Politik Internasional
}

\author{
Siti Imalia Tanjung \\ Magister Hubungan Internasional Fakultas Ilmu Sosial dan Politik \\ Universitas Airlangga Surabaya \\ siti.imalia.tanjung-2019@fisip.unair.ac.id
}

\begin{tabular}{l}
\hline Keywords: \\
\hline COVID-19, \\
Crisis, \\
International \\
Political \\
Economy \\
\hline
\end{tabular}

\begin{abstract}
The unprecedented COVID-19 pandemic has caused people all over the world to panic. The World Health Organization (WHO) is taking proactive measures to prevent the spread of the virus, by directing countries around the world to take measures such as social distancing, physical distancing, quarantine, and regional restrictions or known as lock down which ultimately affects various sectors of life. . This research journal discusses the Impact of Covid-19 on International Political Economy Stability. This paper focuses on the impacts of the COVID-19 pandemic phenomenon, and various global problems in general, and positions the COVID-19 pandemic phenomenon from the point of view of international political economy studies as a study of International Relations. This writing uses a qualitative descriptive research method by using a literature study to systematically study the impact of the COVID-19 Pandemic on the stability of the International Political Economy, in order to formulate future policies in combating the pandemic. After reviewing and analyzing some of the literature, it was concluded that the stability sector of the International Political Economy is the most vulnerable and threatened to the impact of COVID-19.
\end{abstract}

Kata Kunci:

Covid-19, Ekonomi Politik Internasional Krisis

\begin{abstract}
Abstrak
Pandemi COVID -19 yang belum terjadi sebelumnya mengakibatkan masyarakat di seluruh dunia mengalami kepanikan. World Health Organization (WHO) mengambil tindakan proaktif untuk mencegah penyebaran virus, dengan mengarahkan Negara- negara di seluruh dunia untuk melakukan tindakan seperti, social distancing, physical distancing, karantina, dan pembatasan wilayah atau di kenal lock down yang pada akhirnya mempengaruhi berbagai sektor kehidupan. Jurnal penelitian ini membahas tentang Dampak Covid - 19 Dalam Stabilitas Ekonomi Politik Internasional. Tulisan ini memfokuskan pada dampak apa saja dari fenomena pandemic COVID -19, dan berbagai masalah global pada umumnya, dam memposisikan fenomena pandemik COVID -19 ini dari sudut
\end{abstract}


kajian ekonomi politik internasional sebagai kajian dari Hubungan Internasional. Tujuan dari penelitian ini untuk mengetahui bagaimana dampak dari COVID-19 dalam stabilitas ekonomi politik internasional. Penulisan ini menggunakan metode penelitian deskriptif kualitatif dengan menggunakan studi literatur secara sistematis mempelajari dampak Pandemi COVID - 19 dalam stabilitas Ekonomi Politik Internasional, agar dapat menyusun kebijakan di masa depan dalam memerangi pandemi. Setelah meninjau dan menganalisa beberapa literatur disimpulkan bahwa di sektor stabilitas Ekonomi Politik Internasional paling rentan dan terancam terhadap dampak dari COVID -19.

\section{Pendahuluan}

World Health Organization (WHO) mengumumkan COVID-19 yang awal mula nya muncul sebagai pandemik global pada tanggal 11 Maret 2020 (Setiawan, 2020). COVID-19 menyebar dengan cepat ke seluruh dunia dan berdampak pada kesehatan publik dan perkenomian global. Selain itu, COVID-19 juga memiliki implikasi politik yang memaksa Negara- Negara di dunia untuk menyesuaikan dengan kebijakannya. Hampir seluruh Negara di dunia harus bergerak cepat dan maksimal untuk menerapkan langkah-langkah yang akurat dan efektif agar terhindari dari krisis kesehatan, ekonomi, maupun politik. COVID-19 telah menjadi ujian bagi kapabilitas dan kualitas kepemimpinan pemerintahan baik di tingkat global, Nasional, maupun lokal. Di sisi lain, COVID-19 juga merupakan ujian bagi komitmen terhadap prinsip demokrasi, contohnya dalam menjamin penyampaian aspirasi di ruang publik dan memberi kebebasan bagi rakyat untuk terlibat dalam pemerintahan.

Hal tersebut tentu menjadi ujian bagi kapabilitas dan kualitas kepemimpinan pemerintahan baik di tingkat global, nasional, maupun lokal. Di sisi lain, Covid-19 juga merupakan ujian bagi komitmen terhadap prinsip demokrasi, misalnya dalam menjamin penyampaian aspirasi di ruang publik dan memberi kebebasan bagi rakyat untuk terlibat dalam roda pemerintahan. Kondisi ini membuat berbagai Negara di dunia untuk menerapkan kebijakan pembatasan massa, berkerumun, dan keputusan politik seperti: sosial distancing, physical distancing, lock-down, dan berbagai penutupan perbatasan seperti, penghentian kepengurusan dan pemberian visa untuk Warga Negara Asing. Berbagai Negara juga menerapkan penutupan rute penerbangan dan pembatasan terhadap terhadap aktivitas keluar masuk perbatasan untuk Warga Negara Asing, dimana hal ini juga diikuti dengan melakukan repatriasi terhadap Warga Negaranya yang terjebak di 
Negara lain melalui penerbangan darurat maupun memfasilitasi kepulangan untuk Warga Negaranya sendiri. WHO sendiri menekan kan bahwasanya Pandemi COVID - 19 merupakan pandemic yang memerlukan implementasi penuh dari peraturan kesehatan internasional (International Health Regulation/ IHR) sebagai rezim kesehatan internasional (Jose \& Indah Pratiwi Eri Putri, 2021).

Dampak Pandemi Covid 19 bagi kehidupan masyarakat sangat lah cukup besar. Sumber dari situs Kementerian Kesehatan Republik Indonesia mencatat bahwa hingga 7 Juli 2021, Pemerintah Republik Indonesia telah melaporkan bahwa total kasus konfirmasi psitif COVID -19 sebanyak 2.379.397 orang dan ada 62.908 kematian (CFR:2,6\%) terkait COVID-19, dan sebanyak 1.973.388 pasien telah sembuh dari penyakit tersebut. Sementara situasi secara global hingga 7 Juli 2021, total kasus konfirmasi COVID -19 di dunia adalah 184.350.802 kasus dengan 3.992.992 kematian (CFR 2,2\%) di 222 Negara terjangkit dan 149 Negara Transmisi Komunitas (Infeksiemerging.kemkes.go.id, 2021).

Beberapa penelitian dari berbagai bidang pun telah meneliti banyak dampak yang terjadi akibat dari pandemi COVID 19, salah satu nya oleh (Lisbet, 2021), sumber Kompas menyatakan bahwa dampak COVID -19 adalah menurunnya tingkat pertumbuhan ekonomi dunia. International Monetary Fund (IMF) telah menyatakan bahwa pertumbuhan ekonomi dunia menurun sebesar 0,1 -02\% menjadi sebesar 3,3\% pada tahun 2020. Hal ini juga disampaikan oleh Kepala Organization for Economic CoOperation and Development (OECD), Laurence Boone juga telah memperkirakan akan terjadinya perlambatan pada kinerja perekonomian dunia karena berkurang nya jumlah rantai pasokan dan turunnya permintaan atas komoditas (Lisbet, 2021).

Pandemi COVID-19 memberikan dampak yang parah terhadap sektor pariwisata, Organisasi Pariwisata Dunia (UNWTO ) pada bulan Maret 2020 mengumumkan bahwa dampak COVID-19 akan terasa di seluruh rantai pariwisata. Sekitar $80 \%$ usaha kecil dan menengah dari sektor pariwisata dengan jutaan mata pencaharian di seluruh dunia terkena dampak COVID-19 (Sugihamretha, 2020).

Dalam merespon wabah COVID-19, UNWTO telah merevisi prospek pertumbuhan wisatawan internasional negative $1 \%$ hingga 3\%, sehingga berdampak pada menurunnya penerimaan atau perkiraan kerugian US \$ 30 milyar. Asia dan Pasifik akan menjadi wilayah yang terkena dampak terburuk, dengan adanya penurunan kedatangan yang di perkirakan antara 9\% hingga 12\% (Sugihamretha, 2020). 
Dari hasil data yang ada,UNWTO memperkirakan kedatangan wisatawan internasional bisa menurun sebesar 1\% hingga 3\% pada tahun 2020 secara global, atau turun dari perkiraan pertumbuhan 3\% hingga 4\% pada awal Januari 2020 (Gambar 1, dan Gambar2) (Sugihamretha, 2020).

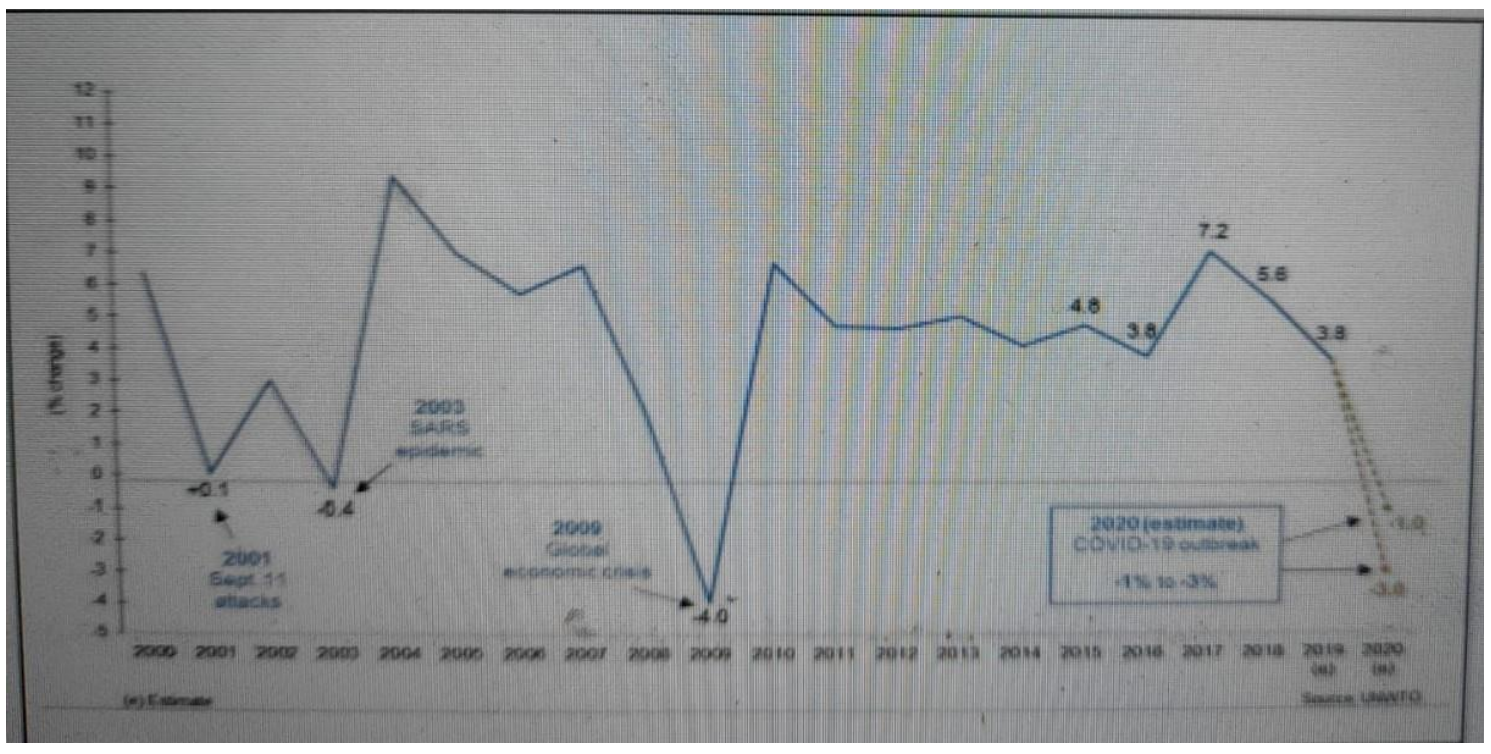

Gambar 1. Revised 2020 Forecast - International Tourist Arrivals, World (\% Change)

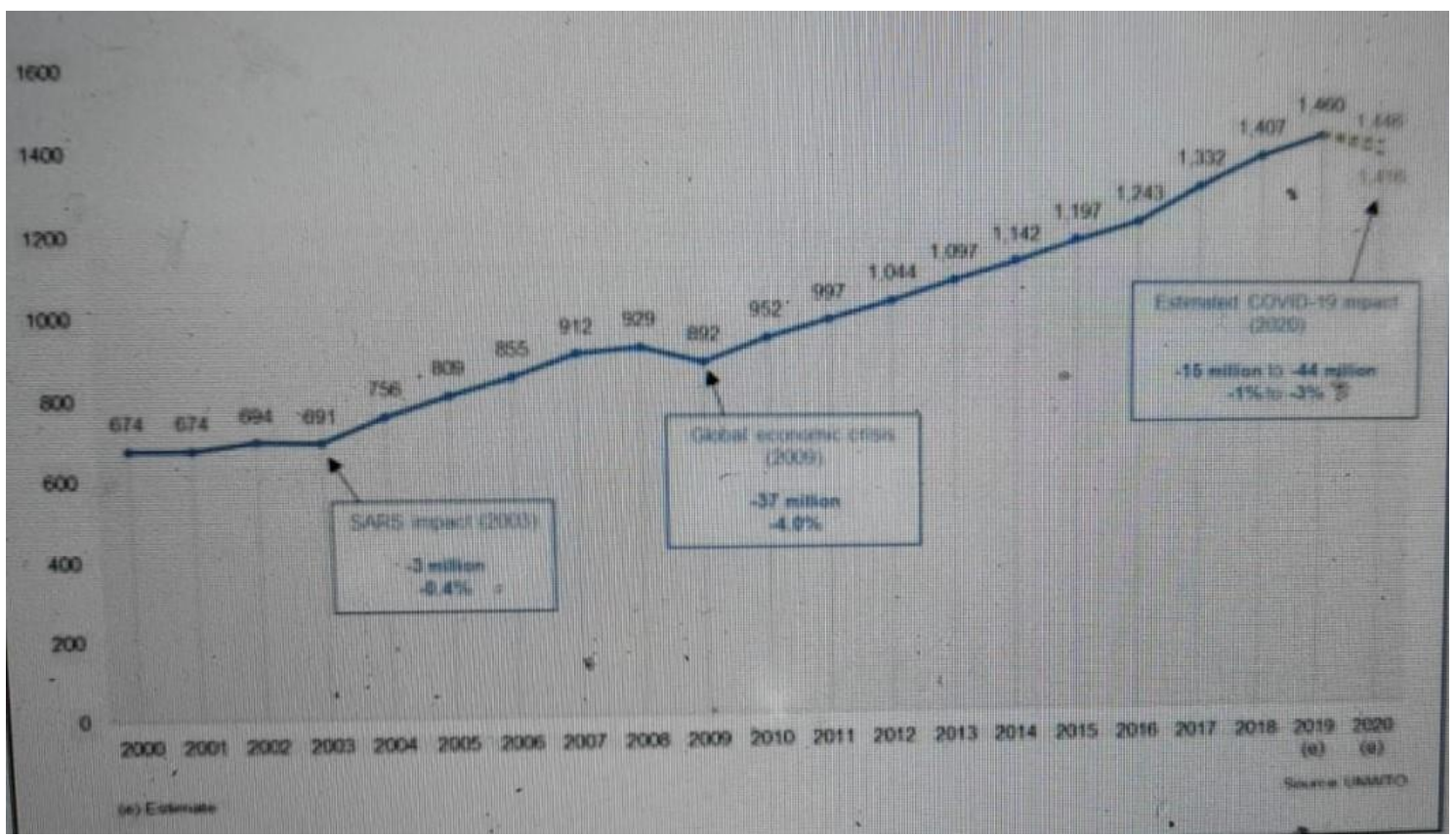

Gambar 2. Revised 2020 Forecast - International Tourist Arrivals, World (Million) 
Mengingat telah menyebarnya pandemi COVID - 19 di lebih dari 200 Negara di dunia, permasalahan ini amat layak harus di pandang sebagai masalah global, bukan masalah satu atau beberapa Negara saja. Fenomena COVID-19 memicu timbulnya berbagai analisis tentang dampak yang terjadi serta respon global yang perlu di siapkan, agar dunia lebih siap di masa akan datang untuk menghadapi goncangan serupa di masa depan. Berbagai upaya telah di lakukan untuk mengatasinya, dari inisiatif- inisiatif dari para pakar yang bersifat domestik, sampai kerjasama bilateral, namun belum menunjukkan hasil yang berarti.

Jika di lihat dari data yang ada, bahwa data menunjukkan bahwa perang melawan Covid 19 yang telah menunjukkan keberhasilan dalam mengurangi wabah, masih di Negara Tiongkok, Hong Kong, Taiwan, Singapura, dan Jepang. Hal ini, tidak diragukan lagi, karena pengalaman mereka dalam menangani epidemi SARS di tahun 2003 (Sikki, 2020). Justru di satu sisi, Negara maju seperti di benua Eropa dan Amerika Serikat malah semakin melemah, efek dari pandemi Covid 19. Salah satu Negara yang paling terpukul sejauh ini adalah Negara Italia. Jika dilihat berdasarkan data dari situs wordometer sebesar 86.498 kasus dengan tingkat kematian sebesar 9.194 jiwa, yang mana Italia memiliki hubungan yang kuat dengan China di hubungan Ekonomi (Sikki, 2020). Di sektor kesehatan nya kewalahan, sehingga membuat Negara Italia harus mengkarantina seluruh bagian, semua toko tutup, kecuali apotik dan toko kelontong. Dengan adanya karantina, makan warga telah di perintahkan untuk tinggal di rumah dan dapat memasuki tempat-tempat umum hanta untuk berbelanja atau bepergian ke tempat kerja yang diperlukan. Kewajiban utang publik dan swasta, seperti sewa rumah, pembayaran Bunga utang ditangguhkan, sehingga memperlambat jalur ekonomi sampai wabah virus corona benar- benar hilang (Sikki, 2020).

Mengacu pada kerjasama bilateral, pemanfaatan kerjasama bilateral sebenarnya sangat memungkinkan pengendalian dalam mengatasi permasalahan - permasalahan yang ada di Negara akibat dari pandemi Covid -19. beberapa Negara menunjukan keberhasilan dalam mengurangi wabah dan berinisiatif membantu Negara lain yang terkena imbas pandemi tersebut demi memulihkan dari segi ekonomi dan kesehatan. Sebagai contoh, Negara Jepang dan Korea Selatan yang cukup sukses dalam penanganan Covid 19 dan menunjukkan keberhasilan dalam mengurangi wabah tersebut.

Seperti diketahui, Jepang melalui pernyataan yang di sampaikan oleh menteri Luar Negeri Jepang Motegi Toshimitsu telah memutuskan mengkontribusikan bantuan 
melalui Organisasi Kesehatan Dunia (WHO) dan UNICEF senilai 1,5 miliar yen. Bantuan darurat tersebut akan di berikan kepada Negara- Negara yang terdampak bencana Covid -19, tidak terkecuali Indonesia (Sebayang, 2020). Menteri Luar Neheri Motegi juga menyampaikan bahwa mutlak penting nya kerjasama antara masyarakat internasional demi mencegah penyebaran wabah ini (Sebayang, 2020).

Menanggapi hal tersebut, Menteri Luar Negeri Indonesia, Retno Marsudi menyampaikan rasa terima kasih atas bantuan yang diberikan Jepang, dan apresiasinya atas kerjasama yang telah dilakukan bersama dengan Jepang. Selain masalah Covid- 19, kedua belah pihak juga menyampaikan komitmen nya dalam hubungan bilateral, dan berkomitmen untuk mengintensifkan dalam bidang kerja sama bilateral, regional dan juga mekanisme G-20 dalam memerangi Covid-19 (Sebayang, 2020).

Selain itu, Korea Selatan pun juga perkuat kerja sama bilateral dalam penanganan Covid - 19, salah satu contohnya ada nya hubungan kerjasama dengan Indonesia. Potensi kolaborasi antara Indonesia dan Korea selatan dalam memerangi Covid-19, antara lain dengan dukungan pemerintah dan sector swasta Korea Selatan untuk penanggulangan Covid-19 di Indonesia (Ekon.go.id, 2020). Selama ini kedua Negara tersebut mempunyai hubungan bilateral yang baik, khususnya dalam bidang investasi, perdagangan (eksporimpor), dan pariwisata, dengan total perdagangan antar dua Negara Asia ini sebesar US\$1.311 juta pada Januari 2020 (Ekon.go.id, 2020). Indonesia menjadi pemasok bahan mentah dan energi untuk industri Korsel.

Indonesia merupakan salah satu tujuan utama investasi dari banyak perusahaan Korsel. Negeri Ginseng itu adalah investor terbesar ke-9 untuk Indonesia di 2019.Total investasi dari Korsel ke Indonesia pada tahun tersebut senilai US\$1,1 miliar (2.952 proyek), menurun 33\% dari tahun sebelumnya yang sebesar US\$1,6 miliar (2.412 proyek). kondisi ini malah menyatukan negara-negara di seluruh dunia yang mengalami kejadian sama. Dibuktikan dengan kerja sama yang lebih kuat lagi untuk mencegah penyebaran virus tersebut dan memitigasi pengaruhnya terhadap bidang ekonomi dan sosial(Ekon.go.id, 2020).

Contoh yang bagus untuk "persatuan dunia" itu adalah Extraordinary G20 Leaders' Summit on COVID-19 yang dilaksanakan beberapa waktu lalu. Indonesia berkomitmen untuk mengimplementasikan hasil dari konferensi tingkat tinggi tersebut, dan menggarisbawahi pentingnya kolaborasi di antara negara-negara dalam menghadapi wabah Covid-19 ini (Ekon.go.id, 2020). 
Karena permasalahan- permasalahan tersebut maka sangat -lah menarik untuk dikaji dan di analisa lebih dalam. Maka berdasarkan latar belakang tersebut penulis menarik permasalahan Dampak COVID -19 dalam Stabilitas Ekonomi Politik Internasional. Tulisan ini akan memfokuskan pada dampak apa saja dari fenomena pandemi COVID -19, dan berbagai masalah global pada umumnya, dan memposisikan fenomena pandemik COVID -19 ini dari sudut kajian ekonomi politik internasional sebagai kajian dari Hubungan Internasional. Sehingga akan menjawab permasalahan bagaimana dampak pandemi COVID - 19 dalam stabilitas Ekonomi Politik Internasional? . Tujuan dari penelitian ini untuk mengetahui bagaimana dampak dari pandemic COVID 1-19 dalam mempengaruhi stabilitas ekonomi politik internasional.

\section{Metode}

Jenis Penelitian dalam penulisan ini menerapkan metode kualitatif deskriptif dengan menjawab pertanyaan penelitian yang diajukan dalam jurnal penelitian ini. Jenis metode kualitatif yang digunakan adalah studi literature dari sejumlah jurnal akademis. Metode kualitatif ini adalah digunakan untuk mengikuti garis metode penelitian ilmu sosial. Metode penelitian harus menguraikan metode yang akan di gunakan dalam mengatasi masalah termasuk dalam metode analisis, yang seharusnya berisi cukup detail yang memungkinkan pembaca untuk mengevaluasi kesesuaian metode serta keandalan dan validitas temuan (Kusno, 2020). Tinjauan literatur pada artikel ini menggunakan analisis kualitatif dalam menjelaskan isu yang dibahas melalui metode document-based dan internet-based berdasarkan studi kontemporer yang relevan.

Menurut yang dikatakan juga oleh (Morrisan, 2019) Penelitian deskriptif digunakan untuk menjelaskan tentang kondisi sosial tertentu. Biasanya digunakan sebagai upaya menjawab pertanyaan penelitian apa, dimana, kapan, dan bagimana.

\section{Hasil dan Pembahasan}

\section{Krisis Global Akibat dari Pandemi Covid -19}

Jika kembali ke sejarah awal mula adanya virus, atau wabah - wabah yang telah menyerang di dunia, Wabah Covid- 19 memang bukan pandemik pertama yang di hadapi oleh dunia Internasional.Tetapi krisis yang terjadi secara global yang diakibatkan dari wabah Covid- 19 lebih parah jika di banding kan wabah- wabah yang menyerang dunia sebelumnya, seperti, MERS, SARS, dan flu burung. Salah satu contoh wabah yang pernah 
menyerang masyarakat Eropa adalah Wabah Bubonic dimana penyebarannya yang sangat cepat. Periode pertama terjadi pada masa perang Peloponnesia yang terjadi pada tahun 430 SM, yang akhirnya disebut Pandemi Peloponnesia. Virus tersebut diduga berasal dari Ethiopia dan menyebar dengan cepat di Athena, ketika pasukan Sparta mengepung. Dua pertiga dari populasi meninggal terjangkit virus tersebut. Thucydides menulis di dalam History of Peloponnesian War di tahun 431 SM, mengatakan bahwa Wabah yang begitu parah dan mematikan, para dokter yang tidak peduli dengannya bukan saja tidak berdaya, tetapi mereka justru yang paling cepat meninggal karena paling banyak berhubungan dengan orang sakit. Penyakit ini menewaskan sekitar hamper $25 \%$ populasi di Athena. Pandemi ini berdampak serius, bahkan menurunkan kepatuhan terhadap aturan dan keyakinan religious dari masyarakat Athena (Rusdi, 2020).

Selanjutnya, pada sekitar tahun 527 hingga 565 sebelum masehi yang di sebut wabah Justinian, sempat menghancurkan kejayaan kerajaan Bizantium. Periode kedua terjadi pada peristiwa kematian hitam yang telah menewaskan sepertiga populasi Eropa. Pada tahun 1720 wabah ini terjadi lagi di pelabuhan Marseille, Prancis yang telah membunuh lebih dari 100 ribu orang. Pada mulanya orang yang berlayar dengan sebuah kapal yang telah terjangkit virus tersebut, kemudian pada saat kapal berlabuh, virus tersebut menular dengan cepat ke warga lainnya. Namun, kasus terbesar ketiga dalam sejarah terjadi pada tahun 1855 di China, yang menewaskan lebih dari 12 juta orang di seluruh dunia. Wabah ini diperkirakan telah menewaskan hampir separuh penduduk Eropa. Wabah ini berasal dari China, Timur Laut India lalu ke danau besar Afrika yang di tularkan oleh tikus hitam. Pada saat itu, untuk mencegah wabah tersebut yang dilakukan hanya menghindari yang sakit. Besarnya keyakinan pandemik akan berakhir karena orang yang terinfeksi dan masih hidup menghasilkan imunitas.

Selanjutnya, pada tahun 1347 - 1351 muncul pandemi yang dinamakan Black Death, yang diperkirakan penyakit ini telah merenggut nyawa dua pertiga populasi Eropa. Efek yang diakibatkan oleh penyakit ini, kulitnya akan menghitam karena pendarahan. Penularan penyakit ini berasal dari sejenis binatang kutu atau tikus hitam. Namun sejarah mencatat bahwa para ilmuwan berkeyakinan bahwa Black Death adalah wabah PES, yang disebabkan oleh bakteri Yersinia (Rusdi, 2020). Pada saat itu, pemerintah kota pelabuhan Ragusa di Italia melakukan karantina terhadap para pelayar untuk membuktikan bahwa mereka tidak membawa penyakit. Pada awalnya, para pelayar ditahan di kapal mereka selama 30 hari. Hukum Venesia menamai kondisi ini sebagai trentino. Kemudian, masa 
isolasi bertambah menjadi 40 hari yang dikenal sebagai quarantine, asal mula kata quarantine dan karantina (Rusdi, 2020).

Pada akhir 2019 lalu, Virus Covid 19 dianggap sebagai pandemik global yang pertama kali muncul di Kota Wuhan, Cina pada akhir 2019 lalu, yang akhirnya menyebar ke seluruh dunia. Virus Corona atau severe acute respiratory syndrome coronavirus (SARS-CoV-2) merupakan virus yang menyerang sistem pernapasan, pneumonia akut, sampai kematian Infeksi akibat virus ini disebut sebagai Covid-19. Penyebarannya yang sangat cepat tersebut membuat Negara- Negara lain merasakan dampak nya. Virus ini menyerang sistem kekebalan tubuh manusia dan mengakibatkan dampak yang sangat serius hingga berujung kepada kematian. Covid 19 ini berhasil mengguncang dan merubah tatanan kehidupan manusia di dunia. Semua Negara- Negara di dunia bergerak cepat memngambil langkah dengan maksud mengurangi penyebaran Covid 19 ini, contoh nya penerapan lock down, social distancing, physical distancing, serta penutupan perbatasan seperti penghentian pemberian visa untuk Warga Negara Asing, yang hampir terjadi di seluruh dunia (Kurniawan, 2021).

Langkah yang dilakukan berupa penutupan rute penerbangan dan pembatasan terhadap aktivitas keluar masuk perbatasan untuk warga negara asing telah dilakukan oleh berbagai negara, yang dimana hal ini diikuti juga dengan melakukan repatriasi terhadap warga negaranya yang terjebak di negara lain melalui penerbangan darurat maupun memfasilitasi kepulangan untuk warga negaranya sendiri. Selain itu banyak bidang yang terdampak dari adanya virus yang sangat berbahaya tersebut, bukan hanya di bidang pendidikan yang terdampak, tetapi dari segi kesehatan, ekonomi, politik, dan juga internasional (Jose \& Indah Pratiwi Eri Putri, 2021).

Jika merujuk kepada WHO atau World Health Organization telah menekan kan bahwa pandemi Covid-19 merupakan pandemi yang memerlukan implementasi penuh dari peraturan kesehatan internasional (International Health Regulation/IHR) sebagai rezim kesehatan internasional. Besaran usaha dalam merespons pandemi global yang berskala besar dengan persebaran yang masif dan berbahaya membuat negara dituntut untuk bersiap dalam merespons pandemi dengan beberapa skenario seperti, Persiapan infrastruktur dan suprastruktur kesehatan nasional; persiapan penanganan penjagaan pintu masuk negara dan perbatasan untuk mencegah kasus infeksi dari migrasi manusia dari luar negeri (kasus impor); perencanaan untuk program sanitasi dan desinfeksi influenza; dan risk-assessment dari kebijakan dan langkah- langkah yang akan diambil 
dalam merespons dan melakukan penilaian dalam efektivitas respons untuk penanganan masalah kesehatan selama pandemi global sesuai dengan apa yang telah ditetapkan oleh badan kesehatan dunia atau WHO (Jose \& Indah Pratiwi Eri Putri, 2021).

Fenomena Covid-19 yang terjadi dan dialami oleh hampir seluruh Negara di dunia menimbulkan krisis dari berbagai bidang yang sangat serius yang memicu timbulkan berbagai analisis dampak yang terjadi serta respon yang perlu di siapkan, agar dunia lebih siap di masa akan datang untuk menghadapi goncangan serupa di masa depan. Berbagai upaya telah dilakukan untuk mengatasi nya misalnya seperti inisiatif-inisiatif yang bersifat domestik, sampai dengan kerjasama bilateral, untuk menanggulangi krisis namun belum menunjukkan hasil yang berarti.

Jika di lihat dari sudut perspektif hubungan internasional Covid-19 dipandang sebagai penyebab utama dari krisis global, sehingga memberikan pemahaman baru di mana para ahli dalam sistem internasional bekerja sama dalam penanganan krisis global yang muncul dalam level yang terduga. Namun dapat dipastikanapabila teori realis berhasil menjelaskan bahwa sistem internasional bersifat anarki maka dapat dipastikan bahwa muncul satu pertanyaan mengenai legitimasi label sistem internasional yang anarki tersebut yang dapat dipandang baik dalam kerja sama yang dilakukan di tengah pandemi maupun persaingan setiap negara dalam meningkatkan kemampuan mereka menghadapi pandemi Covid-19 (Jose \& Indah Pratiwi Eri Putri, 2021).

Di harapkan dalam tingkat internasional, usaha kerjasama dan respons yang ada berfokus untuk mengurangi dampak besar melalui usaha-usaha demi memperlambat laju penyebaran virus, serta untuk mengurangi dari infrastruktur dan sumber daya medis yang terbatas dalam lonjakan kasus infeksi yang begitu besar dengan kontrol dan pengawasan ketat. Namun usaha ini terhambat akan kondisi ekonomi masyarakat yang beragam serta untuk menghindari efek domino. Pandemi Covid- 19 membuat setiap negara harus melakukan hal-hal apapun yang dinilai perlu untuk penanganan virus ini, dan pandemi Covid-19 telah mempengaruhi peta politik dan pola kerja sama antar-negara di mana dalam hal ini dinilai bahwa dunia terbelah dalam mengambil sikap terhadap persebaran pandemi global.

Jika di lihat dari laju penyebaran virus Covis 19 yang terjadi di hampir di 213 di seluruh Negara hingga 30 Agustus 2020, yaitu di Amerika Utara, Amerika Selatan, Eropa, Asia, Afrika, oceania dan Asia, dari hari ke hari angka kasus dan kematian terus bertambah. Secara akumulatif ada 25.390.069 kasus, terdiri dari 850.615 kasus kematian, 
17.709.077 orang sembuh, 6.830.377 kasus aktif, da nada 61.101 kasus seris (kritis). Mereka tersebar di Amerika Utara 28,8\%, Asia 27,56\%, Amerika Selatan 24,59\%, Eropa 14,0\%, Afrika 4,92 \% dan Australia 0,11\% . Secara rinci angka kasus kematian, kasus aktif, kasus kritis, total tes dan jumlah populasi dapat di lihat pada tabel 1 berikut dibawah ini: (Junaedi \& Salistia, 2020)

Tabel 1. Kasus Pandemi COVID-19 per 30 Agustus 2020

Sumber: diolah dari Worldometer 30 Agustus 2020

\begin{tabular}{|l|l|l|l|l|l|l|}
\hline Kawasan & Negara & Kasus & Meninggal & Sembuh & Test & Populasi \\
\hline $\begin{array}{l}\text { Amerika } \\
\text { Selatan }\end{array}$ & 14 & 6244321 & 201164 & 4834353 & 26659437 & 431343377 \\
\hline & $6.57 \%$ & $24.59 \%$ & $23.65 \%$ & $27.30 \%$ & $5.80 \%$ & $5.29 \%$ \\
\hline $\begin{array}{l}\text { Amerika } \\
\text { Utara }\end{array}$ & 39 & 7312603 & 270532 & 4203181 & 90877241 & 589866928 \\
\hline & $18.31 \%$ & $28.80 \%$ & $31.80 \%$ & $23.73 \%$ & $19.77 \%$ & $7.23 \%$ \\
\hline Eropa & 48 & 3555640 & 207400 & 2065754 & 115850651 & 747707013 \\
\hline & $22.54 \%$ & $14.00 \%$ & $24.38 \%$ & $11.66 \%$ & $25.20 \%$ & $9.16 \%$ \\
\hline Asia & 49 & 6998654 & 141205 & 5602612 & 188590955 & 4615185050 \\
\hline & $23.00 \%$ & $27.56 \%$ & $16.60 \%$ & $31.64 \%$ & $41.02 \%$ & $56.55 \%$ \\
\hline Afrika & 57 & 1250375 & 29633 & 979996 & 11071333 & 1345627090 \\
\hline & $26.76 \%$ & $4.92 \%$ & $3.48 \%$ & $5.53 \%$ & $2.41 \%$ & $16.49 \%$ \\
\hline Oceania & 6 & 28,476 & 681 & 23,181 & $7,010,852$ & $40,989,145$ \\
\hline & $2.82 \%$ & $0.11 \%$ & $0.08 \%$ & $0.13 \%$ & $1.53 \%$ & $0.50 \%$ \\
\hline Total & 213 & 25390069 & 850615 & 17709077 & 440060469 & $7,770,718,603$ \\
\hline
\end{tabular}

Jika dianalisa dari tabel tersebut diatas, secara kuantitas, kawasan Amerika Utara dan Asia secara kuantitas, kawasan Amerika Utara dan Asia menjadi kawasan paling banyak terdampak kasus pandemi. Sementara Eropa termasukk kawasan paling banyak melaporkan kematian akibat COVID-19. Amerika Utara yang memiliki penduduk 589,9 juta jiwa mencatatkan 7,313 juta kasus dan 270,5 ribu kematian. Asia dimana ada 4,615 milyar manusia tinggal, memiliki catatan 6,999 juta kasus dan 141 ribu kematian. Berikutnya adalah Amerika Utara (dihuni 431,34 juta memiliki 6,244 juta kasus dan 201 ribu kematian. Urutan berikutnya adalah Eropa, Afrika, dan Oceania. Eropa memiliki 355,56 juta kasus dan 270,532 kematian. Afrika memiliki 1,25 juta kasus dan 29.633 kematian. Sementara Oceania yang dihuni 40,9 juta jiwa baru mencatatkan 28.476 kasus dan 681 kematian akibat COVID-19.

Memperhatikan grafik harian, pandemik ini sudah melewati fase dua gelombang. Tambahan kasus dan kematian harian masih terbilang tinggi. Selama bulan Agustus, setiap hari kasus bertambah lebih dari 250 ribu, sementara angka kematian rata-rata 
bertambah sekitar 6.000 per hari. Dihubungkan dengan dampak ekonomi yang terjadi di sejumlah Negara terdampak selama masa pandemik.

Data Fiskal IMF Juli 2020, menyajikan proyeksi pertumbuhan sejumlah negara terdampak selama masa pandemik. Dampak pandemik Covid terhadap pertumbuhan ekonomi punya variasi yang lebar. IMF membuat tiga katagori negara; yaitu: Advance Economiies (negara maju), Emerging Market and Middle Income Economes (negara berkembang dan menengah), serta negara Low Income Developing Countries (negara miskin). Tim ekonomi IMF memprediksi selama pandemi COVID-19 negara-negara maju (Advance Country) mengalami kontraksi pertumbuhan ekonomi antara $-5,5 \%$ (Jerman) hingga Negara AS sebesar -15,4\%. Selama pandemi di perkirakan rata - rata Negara- Negara maju mengalami pertumbuhan minus 10,7\% (Junaedi \& Salistia, 2020). Berikut secara rinci pada table 2 berikut dibawah ini:

Tabel 2. Kontraksi Pertumbuhan Ekonomi

Sumber: Monitoring Fiscal IMF, Juni 2020

\begin{tabular}{|c|c|c|c|c|c|c|c|c|c|}
\hline & & & & & & & & & Projection S \\
\hline & 2012 & 2013 & 2014 & 2015 & 2016 & 2017 & 2018 & 2019 & 2020 \\
\hline World & -3.8 & -2.9 & -2.9 & -3.3 & -3.4 & -3.0 & -3.1 & -3.7 & -9.9 \\
\hline Advanced Economies & -5.5 & -3.7 & -3.1 & -2.6 & -2.6 & -2.3 & -2.6 & -3.0 & $-\mathbf{1 0 . 7}$ \\
\hline United States1 & -8.0 & -4.6 & -4.0 & -3.6 & -4.3 & -4.5 & -5.7 & -5.8 & -15.4 \\
\hline Euro Area & -3.7 & -3.0 & -2.5 & -2.0 & -1.4 & -0.9 & -0.5 & -0.7 & -7.5 \\
\hline France & -5.0 & -4.1 & -3.9 & -3.6 & -3.5 & -2.8 & -2.3 & -3.0 & -9.2 \\
\hline Germany & 0 & 0 & 0.6 & 0.9 & 1.2 & 1.2 & 1.9 & 1.4 & -5.5 \\
\hline Italy & -2.9 & -2.9 & -3.0 & -2.6 & -2.4 & -2.4 & -2.2 & -1.6 & -8.3 \\
\hline Spain2 & 10.7 & -7.0 & -5.9 & -5.2 & -4.3 & -3.0 & -2.5 & -2.6 & -9.5 \\
\hline Japan & -8.6 & -7.9 & -5.6 & -3.8 & -3.7 & -3.1 & -2.4 & -2.8 & -7.1 \\
\hline United Kingdom & -7.6 & -5.5 & -5.6 & -4.6 & -3.3 & -2.5 & -2.2 & -2.1 & -8.3 \\
\hline Canada & -2.5 & -1.5 & 0.2 & -0.1 & -0.5 & -0.1 & -0.4 & -0.4 & -11.8 \\
\hline Others & 0.4 & 0.2 & 0.2 & 0.1 & 0.7 & 1.4 & 1.4 & 0 & -5.3 \\
\hline $\begin{array}{l}\text { Emerging Market and } \\
\text { Middle- } \\
\text { Income Economies }\end{array}$ & -0.9 & -1.5 & -2.5 & -4.4 & -4.8 & -4.1 & -3.8 & -4.8 & -9.1 \\
\hline $\begin{array}{l}\text { Excluding MENAP Oil } \\
\text { Producers }\end{array}$ & -1.9 & -2.3 & -2.7 & 4.0 & -4.4 & -4.0 & -4.0 & -5.0 & -9.0 \\
\hline Asia & -1.6 & -1.8 & -1.9 & -3.3 & -3.9 & -4.0 & -4.5 & -6.0 & -9.9 \\
\hline China & -0.3 & -0.8 & -0.9 & -2.8 & -3.7 & -3.8 & -4.7 & -6.4 & -11.2 \\
\hline India & -7.5 & -7.0 & -7.1 & -7.2 & -7.1 & -6.4 & -6.3 & -7.4 & -7.4 \\
\hline Europe & -0.7 & -1.5 & -1.4 & -2.7 & -2.9 & -1.8 & 0.4 & -0.7 & -6.1 \\
\hline Russia & 0.4 & -1.2 & -1.1 & -3.4 & -3.7 & -1.5 & 2.9 & 1.9 & -4.8 \\
\hline Latin America & -2.9 & -3.2 & -5.0 & -6.8 & -6.2 & -5.4 & -5.2 & -4.0 & -6.7 \\
\hline Brazil & -2.5 & -3.0 & -6.0 & 10.3 & -9.0 & -7.9 & -7.2 & -6.0 & -9.3 \\
\hline Mexico & -3.7 & -3.7 & -4.5 & -4.0 & -2.8 & -1.1 & -2.2 & -2.3 & -4.2 \\
\hline
\end{tabular}




\begin{tabular}{|l|l|l|l|l|l|l|l|l|l|}
\hline MENAP & 5.6 & 3.9 & -1.5 & -8.5 & -9.6 & -5.8 & -2.9 & -3.8 & -9.8 \\
\hline Saudi Arabia & 11.9 & 5.6 & -3.5 & - & - & -9.2 & -5.9 & -4.5 & -12.6 \\
\hline South Africa & -4.4 & -4.3 & -4.3 & -4.8 & -4.1 & -4.4 & -4.1 & -6.3 & -13.3 \\
\hline $\begin{array}{l}\text { Low-Income } \\
\text { Developing } \\
\text { Countries }\end{array}$ & $\mathbf{2 . 0}$ & $\mathbf{- 3 . 3}$ & $\mathbf{- 3 . 2}$ & $-\mathbf{3 . 8}$ & $\mathbf{- 3 . 7}$ & $-\mathbf{3 . 6}$ & $\mathbf{- 3 . 8}$ & $\mathbf{- 4 . 1}$ & $\mathbf{5 . 7}$ \\
\hline Nigeria & & & & & & & & & \\
\hline
\end{tabular}

\section{Dampak COVID-19 Terhadap Ketidakstabilan Ekonomi Politik Internasional}

Dampak Covid-19 menyerang dan mengakibatkan krisis hampir di semua negara di dunia. Sehingga menyebabkan permasalahan - permasalahan terbaru bagi semua Negara di dunia yang sulit untuk di selesaikan. Dampak tersebut merubah kebiasaan dan tatanan juga di ekonomi politik internasional dan berubah mengikuti perkembangan Covid-19. Jika membahas terkait dengan Ekonomi politik internasional adalah kajian yang menyorot hubungan ekonomi dan politik, statemarket, dalam skala global. Ekonomi politik internasional mempunyai berbagai fokus (Irawan, 2020) .

Dengan muncul nya Covid-19 ini segala dinamika politik internasional sangat berfokus pada upaya penanganan virus mematikan itu. Sehingga Pandemi Covid-19 bisa di jadikan sebagai babak baru dalam pergerakan politik global, karena semua Negara terkena dampak pandemi ini. Selain sektor pariwisata, yang pastinya berpengaruh juga pada Ekonomi tiap Negara, dikarenakan di batasi nya para Warga Negara Asing untuk berkunjung di Negara lain, lock down dan lain sebagai nya. Virus corona juga berdampak terhadap supply chain mengingat Cina, khususnya Wuhan menjadi daerah penyuplai beberapa bahan baku. Menurut yang dikatakan oleh Dr Irma Indrayani, M.Si pakar Hubungan Internasional dari Universitas Nasional Jakarta (Unas) berpendapat bahwa ada tiga sektor yang terkena dampak, yaitu Harga Minyak, Supply Chain, dan Bisnis perjalanan, namun selain tiga faktor penting ini memang semua lapisan merasakan dampaknya.

Sejak munculnya globalisasi, dan dunia telah menjadi lebih dekat dan orang dapat terhubung dengan mudah dan berinteraksi satu sama lain tanpa menghadapi hambatan serius. Hal ini mengakibatkan di satu sisi bermanfaat dan di sisi lainnya malah merugikan bagi bidang sosial, politik, dan ekonomi. Gerakan bebas dan tanpa hambatan tersebut yang dibawa oleh globalisasi telah merangsang pembangunan sosial, ekonomi, tetapi juga telah menjadi saluran untuk penyebaran penyakit (Kusno, 2020). 
Akibatnya, karena perkembangan teknologi yang terkait dengan globalisasi tersebut, imbasnya ketika terjadi pandemi COVID-19 ini yang telah berubah menjadi pandemi besar, sangat mempengaruhi lajur pergerakan orang-orang di seluruh dunia terlepas dari lokasi geografisnya. Konsep lain dari ekonomi politik internasional adalah Globalisasi, yang menggambarkan perubahan "lingkungan" interaksi manusia (Kusno, 2020) .

Banyak akademisi dan para ahli secara khusus membahas tentang globalisasi, misalnya adalah Joseph Stiglitz, Mansbach, dan Hyland Eriksen. Globalisasi menjelaskan tentang perubahan mendasar dari dunia yang tersekat-sekat akibat polarisasi antara kubu komunisme dan liberal, menjadi yang terkoneksi satu sama lain. Halangan politik bagi terkoneksinya pemerintahan dan masyarakat dari berbagai negara dengan mereka yang berasal dari negara lain menjadi amat berkurang setelah Perang Dingin berakhir di awal 1990-an (Irawan, 2020). Faktor lain yang membentuk globalisasi adalah penemuan teknologi baru yang mendukung keterhubungan lintas batas ini.

Dari Segi Ekonomi sendiri, dampak Covid -19 masih sedikit yang diketahui dari segi makro jangka menengah hingga panjang dari pandemi global. Fakta yang terjadi, pandemi Covid - 19 yang memiliki efek luar biasa tentang globalisasi dan yang tepenting juga dari segi ekonomi, sampai sekarang untuk mengatasi virus corona atau efektivitas upaya untuk membatasi penyebarannya tidak jelas; dengan demikian, pada saat ini membuat prediksi ekonomi kurang jelas dan sangat sulit tentang kemungkinan perilaku agen ekonomi (Kusno, 2020).

Pandemi COVID-19, pada gilirannya, memiliki efek luar biasa bagi globalisasi dunia salah satu nya pada aspek ekonomi. Bisa dikatakan bahwa Banyak dari efek tersebut sudah disaksikan pada saat ini, dan akan berlanjut pada jangka pendek, setidaknya selama periode memerangi pandemi.

Menurut Butler (2020), menyatakan bahwa permasalahan ekonomi di berbagai kawasan memberikan dampak dalam skala yang tidak pernah dibayangkan sebelumnya. Hal ini dibuktikan dengan angka kemiskinan yang meningkat tajam seperti yang diprediksi oleh Bank Dunia dari 8,1\% pada 2019 menjadi 8,6\% pada tahun 2020 yang diartikan akan ada lebih dari 50 juta orang yang akan mengalami kemiskinan akibat pandemi Covid-19 yang di mana negara sendiri tentunya akan berjuang untuk menghadapi economic fallout yang juga membuat berbagai investasi dan valuasi perdagangan yang menurun hingga menyentuh $32 \%$ dan berdampak pada negara maju 
maupun negara berkembang (Jose \& Indah Pratiwi Eri Putri, 2021) Hal ini diiringi dengan masalah-masalah keamanan sosial seperti krisis politik, di mana tingkat kepercayaan masyarakat kepada pemerintah menurun drastis. Angka kriminalitas meningkat dengan bertambahnya jumlah pengangguran di suatu negara, ditambah dengan sulitnya penegakan hukum terutama di negara-negara yang dikuasai mafia. Tidak adanya ketegasan hukum oleh polisi dan perangkat pemerintahan, serta masalah-masalah yang menimpa negara-negara konflik dan failed states yang di perparah dengan ketidakhadiran pemerintahan pusat yang kuat serta tidak adanya rule of law (Jose \& Indah Pratiwi Eri Putri, 2021).

Selain dampak dari ekonomi yang terjadi imbas dari adanya pandemi Covid -19, berpengaruh juga di hubungan internasional yang sebenarnya berkaitan satu sama lain. Beberapa hasil positif yang terjadi, hubungan antar Negara, karena akibat dari adanya pandemi ini maka negara saling membantu satu sama lain dan mencoba untuk melawan pandemi melalui kolaborasi yang bersahabat. Tantangan sistemik yang belum pernah terjadi sebelumnya dilemparkan oleh pandemi COVID-19, dan respons global yang sudah terlihat, dapat membantu perkembangan transformasi pola tradisional hubungan donorpenerima bantuan menuju model kerja sama internasional yang baru antara semua Negara (Kusno, 2020). Bahkan selama pandemi, hubungan antara Cina dan AS masih terjalin dengan baik, dan tetap berjalan lancar, meskipun masih ada perang kata-kata dan tuduhan tentang awal mula Covid-19 tetap ada, dan diskusi upaya bersama juga terjadi antara kedua negara untuk memerangi pandemi.

Jika di analisa kembali dampak dari Covid -19 di dalam Ekomomi politik internasional saling berkaitan satu sama lain. Pandemi Covid-19 telah membawa perubahan multidimensional dalam hubungan internasional, terutama pada tatanan politik ekonomi dan pembangunan internasional. Perubahan-perubahan tersebut membuat para negara dituntut untuk lebih resilien dan menetapkan usaha untuk mengatasi isu transnasional yang berdampak langsung terhadap manusia (rakyat) dan tidak selalu pada negara. Tidak dipungkiri, pada akhirnya mengakibatkan perubahan tatanan global, politik, ekonomi dan hubungan internasional antar negara di Dunia. Adanya pandemi Covid-19 banyak negara yang harus menutup wilayahnya. Aktivitas transportasi dan pergerakan masyarakat pun dibatasi. Hubungan bilateral dan multilateral antar Negara terganggu akibat pandemi ini. Persoalan etis, moral, keadilan, kesehatan, pemerataan akses vaksin, dan pertarungan Negara-negara besar mewarnai politik global saat ini dan 
pada kondisi pandemi ini. Sehinnga tren utama menguat yaitu rasa nasionalisme, adanya gotong royong untuk saling membantu satu sama lainnya.

Sementara di balik itu juga dibarengi dengan melemahnya multilateralisme sehingga Negara tidak lagi berharap bantuan atau kerjasama dengan Negara lain. Sehinnga sangat lah logis jika Pandemi Covid bisa dikaitkan dengan Ekonomi politik internasional, karena semua Negara sangat terpengaruh karena pandemi Covid - 19 ini.

\section{Kesimpulan}

Ketika dunia berhadapan dengan ancaman pandemi COVID-19. Hal itu menyebabkan pergeseran tatanan global, terutama yang terkait dengan pemetaan kekuatan ekonomi politik internasional. Kelompok negara maju yang berada di bagian utara dunia, harus menghadapi kenyataan bahwa mereka harus mempersiapkan diri untuk melakukan penyesuaian pasca pandemi. Virus Corona atau severe acute respiratory syndrome coronavirus (SARS-CoV-2) merupakan virus yang menyerang sistem pernapasan, pneumonia akut, sampai kematian Infeksi akibat virus ini disebut sebagai Covid-19 virus ini tidak hanya menyebabkan menurunkan kesehatan seseorang juga menurunkan pertumbuhan ekonomi secara Global, juga dampak di sektor politik internasional. Pasalnya, virus ini mampu menular dan menyebar dengan cepat hanya melalui sentuhan dari satu orang ke orang lainnya. Sehingga sangat berdampak pada segala sektor di dunia. Jika di lihat dari sudut perspektif hubungan internasional Covid19 dipandang sebagai penyebah utama dari krisis global, sehingga memberikan pemahaman baru di mana para ahli dalam sistem internasional bekerja sama dalam penanganan krisis global yang muncul dalam level yang terduga. Namun bisa di pastikan jika dunia internasional, para tim ahli dalam berbagai bidang dapat mengambil sikap yang lebih ter struktur, bahu membahu saling membantu, dan menerapkan stabilitias yang baik aantar negara dalam penanganan Covid -19 maka krisis ini akan cepat teratasi dan terkendali dengan baik.

Pandemi dapat memiliki efek hubungan internasional setidaknya dalam dua cara: pertama, mempengaruhi program ekonomi yang ada dan yang akan datang di bawah pemerintah untuk kerjasama pemerintah khususnya antara China dan negara - negara lain, dan kedua, kemitraan baru dan persahabatan yang didorong oleh bantuan dan bantuan (terutama terkait medis) pertukaran antar pemerintah. Yang pertama terutama berkaitan dengan peningkatan investasi Cina secara global 


\section{Daftar Pustaka}

Ekon.go.id. (2020). Indonesia Perkuat Kerja Sama Bilateral dengan Korsel dalam Penanganan Pandemi Covid-19. Retrieved from Ekon.go.id website: https://www.ekon.go.id/unduh/info_sektoral/33/berita-indonesia-perkuat-kerjasama-bilateral-dengan-korsel-dalam-penanganan-pandemi-covid-19

Infeksiemerging.kemkes.go.id. (2021). Situasi Terkini Perkembangan Coronavirus Disease (COVID-19) 8 Juli 2021. Retrieved July 23, 2021, from infeksiemerging.kemkes.go.id

Irawan, J. (2020). FENOMENA COVID-19: DAMPAK GLOBALISASI DAN REVITALISASI MULTILATERALISME. Jurnal Ilmiah Hubungan Internasional. https://doi.org/10.26593/jihi.v0i0.3877.47-52

Jose, H. S., \& Indah Pratiwi Eri Putri. (2021). TATANAN GLOBAL PADA PEMBANGUNAN DAN EKONOMI POLITIK INTERNASIONAL SELAMA DAN PASCA PANDEMI COVID-19. Jurnal Ilmiah Penalaran Dan Penelitian Mahasiswa, 5.

Junaedi, D., \& Salistia, F. (2020). Dampak Kawasan dan Status Negara Terhadap Pertumbuhan Ekonomi Negara-Negara Terdampak Covid-19. Al-Kharaj : Jurnal Ekonomi, Keuangan \& Bisnis Syariah. https://doi.org/10.47467/alkharaj.v3i2.187

Kurniawan, M. B. (2021). Politik Hukum Pemerintah dalam Penanganan Pandemi Covid19 Ditinjau dari Perspektif Hak Asasi atas Kesehatan. Jurnal HAM. https://doi.org/10.30641/ham.2021.12.37-56

Kusno, F. (2020). Krisis Politik Ekonomi Global Dampak Pandemi Covid-19. Anterior Jurnal. https://doi.org/10.33084/anterior.v19i2.1495

Lisbet. (2021). Penyebaran covid-19 dan Respons Internasional. Info Singkat Pusat Penelitian Dan Kajian DPR-RI.

Morrisan. (2019). Riset Kualitatif Edisi Pertama. Jakarta: Kencana.

Rusdi, R. (2020). Pandemi Penyakit dalam Sejarah dan Dampaknya Terhadap Gejolak Sosial Politik. Diakronika. https://doi.org/10.24036/diakronika/vol20-iss1/146

Sebayang, R. (2020). Jepang Beri 1.5 M Yen ke Negara Terdampak Corona, RI Dapat? Retrieved September 2, 2021, from CNBC website: https://www.cnbcindonesia.com/news/20200324135205-4-147258/jepang-beri15-m-yen-ke-negara-terdampak-corona-ri-dapat 
Setiawan, A. (2020). Politik Luar Negeri Indonesia COVID-19: Penyelamatan dan Kerjasama. Independen, Jurnal Politk Indonesia Dan Global.

Sikki, K. L. (2020). Kebijakan Ekonomi Arab Saudi Dalam Mengantisipasi Pandemi Covid-19. Journal of Islamic Civilization. https://doi.org/10.33086/jic.v2i1.1517

Sugihamretha, I. D. G. (2020). Respon Kebijakan: Mitigasi Dampak Wabah Covid-19 Pada Sektor Pariwisata. Jurnal Perencanaan Pembangunan: The Indonesian Journal of Development Planning. https://doi.org/10.36574/jpp.v4i2.113 